\title{
TEOLOGI HAKIMIYAH: BENIH RADIKALISME ISLAM
}

\section{Iman Fauzi Ghifarie}

Pascasarjana Religious Studies UIN SGD Bandung

e-mail:ghifarie@uinsgd.ac.id

DOI: http://dx.doi.org/10.30983/islam_realitas.v2i1.96

\begin{abstract}
This article examines the theological issues called hakimiyah as the seeds of extremism, fundamentalism, radicalism religion (Islam) that manifests itself in the behavior and acts of violence in the name of religion. The rise of radicalism among young people in the form of violence, terrorism, suicide bombing is coming from theology hakimiyah and istisybad doctrine (martyrdom) in order to get guarantee into heaven surrounded by 40 angels. It is because they always spread hatred and hostility and beliefe to takfiri concept (infidelity) to resolve any different opinion, a belief that led to vigilante, even to take the life of another person as the main ticket to heaven. If the actions and behaviors that hurt the conscience and the bumanitarian aspect continue to be done systematically, and sustained by the younger generation, then what would the fate of Mother Earth become? Of course, it is possible to give the birth of the Islamic State of Indonesia Malaysia. Meanwhile, Islam forbids any acts that damage, destroy, injure, and kill for no good reason. Even in a war, moral principles, morality, and ethics should be a guide and reference. Radicalism, terrorism, limbs and destruction have neither religion nor country. Everyone who embraces the ideology which spread terror to the people who live safely, and bring damage to plants and animals are terrorist. No one can give any sentence of punishment "deviant," "infidel," "kill" to the groups which have different understanding, except Allah, the supreme judges. When we do that kind of behavior and actions, then we are more powerful than God.
\end{abstract}

Keywords: Young Genereation, Radicalism, Hakimiyah Theology, Istisyhad Doctrine

\section{Abstrak}

Tulisan ini mengkaji persoalan teologi Hakimiyah sebagai benih ekstremisme, fundamentalisme, radikalisme agama (Islam) yang mewujud dalam perilaku, tindakan kekerasan atas nama agama. Maraknya gerakan radikalisme di kalangan anak muda dalam bentuk aksi kekerasan, terorisme, bom bunuh diri ini yang bersumber dari teologi Hakimiyah dan doktrin Istisyhad (mati syahid) demi mendapatkan jaminan masuk surga yang dikelilingi 40 bidadari. Pasalnya, mereka selalu menebarkan kebencian, permusuhan dengan memengang teguh pemahaman takfiri (pengkafiran) untuk menyelesaikan setiap perbedaan pendapat, keyakinan yang berujung pada cara main hakim sendiri, hingga menghilangkan nyawa orang lain sebagai tiket utama masuk surga. Jika tindakan dan perilaku yang melukai aspek kemanusiaan dan hati nurani ini terus dilakukan secara sistematis, berkelanjutan oleh generasi muda, maka apa jadinya nasib bumi pertiwi. Tentunya, tidak menutup kemungkinan akan lahirnya Negara Islam Indonesia Malaysia. Padahal, ajaran Islam mengharamkan setiap perbuatan yang merusak, membinasakan, melukai, dan membunuh tanpa alasan yang benar. Dalam peperangan sekalipun, prinsip-prinsip moral, akhlak, dan etika harus dijadikan pedoman dan acuan. Radikalisme, terorisme, ekstremitas dan pengrusakan tidak punya agama dan tidak pula negara. Setiap orang yang menganut ideologi yang menebarkan teror kepada orang-orang yang hidup aman, serta merusak tumbuhan dan hewan adalah teroris.Tiada seseorang yang dapat memberikan penyebutan hukuman "sesat," "kafir," "bunuh" terhadap kelompok yang berbeda pemahaman, keyakinan kecuali hakim yang Maha Tinggi, Allah Swt. Bila perilaku dan tindakan itu kita lakukan, maka kita lebih berkuasa dari Tuhan.

Kata Kunci : Anak Muda, Radikalisme, Teologi Hakimiyah, Doktrin Istisyhad

\section{Latar Belakang}

Fenomena radikalisme di Indonesia hingga hari ini masih menjadi perbincangan yang menarik dan terus menghangat. Pasalnya, radikalisme masih menjadi masalah serius bagi banyak kalangan. Jika kita berefleksi ke 
belakang, semenjak tragedi WTC dan Pentagon, 11 September 2001, kosa kata terorisme dan radikalisme Islam memang banyak bertaburan di media massa, buku, dan jurnal akademik.

Selama ini, banyak orang menganggap kategorisasi itu hasil ciptaan Barat untuk memecah-belah umat Islam serta mencegah umat Islam maju dan bersatu. Karena itu, tidak aneh jika ketika terjadi Bom Bali I pada 2002 dan Bom Bali II, banyak tokoh Islam yang menyatakan bahwa teroris itu hanya "rekaan" Barat untuk merusak citra Islam agar senantiasa terkait dengan tindakan kekerasan dan terorisme.

Namun, ketika kejadian teror di Indonesia terus beruntun, yang diikuti oleh penangkapan para teroris, kita menyaksikan fakta lain berupa testimoni dan jaringan yang dibentuk oleh mereka. Kita bisa tahu bahwa memang ada orang-orang yang mendedikasikan hidupnya untuk menjadi teroris, menggembleng para calon teroris, mengajarkan ilmu teror, dan meyakinkan orang-orang untuk mengikuti pemahaman Islam ala teroris.

Dari fenomena itu, kita bisa mengatakan bahwa radikalisme dan terorisme bukan murni ciptaan Barat, melainkan memang fakta nyata karena ada yang meyakini, memeluk, dan mengembangkannya dari kalangan umat Islam sendiri. ${ }^{1}$

Indonesia memang menjadi lahan subur pelaku kekerasan, radikalisme dan terorisme. Dalam buku laporan Sidney Jones, "Indeks Nama-nama Tertuduh Pelaku Terorisme di Asia Tenggara", Internastional Crisis Group: Working To Prevent Conflict Worldwide, Februari tahun 2005, menunjukkan jumlah tertuduh terpidana terorisme di Indonesia mencapai sebanyak 269 orang.

${ }^{1}$ Ahmad Fuad Fanani, "Fenomena Radikalisme di Kalangan Kaum Muda", Maarif, Vol. 8, No. 1, Juli 2013, h. 4.
Sementara itu dalam penelitian yang dilakukan Puslitbang Kehidupan Keagamaan tahun 2006, tidak ada satupun nama dalam laporan itu. Bila setiap lokasi rata-rata 4 orang saja, maka jumlah tertuduh dan terpidana terorisme mencapai 290-an orang.

Padahal di luar itu para tertuduh sudah dipenjarakan, menunggu proses pengadilan dan sebagian telah dieksekusi mati atau ditembak dalam penggerebegan oleh aparat keamanan. Dalam empat tahun terakhir setelah laporan itu disusun belum ada laporan pasti bahwa yang belum ditangkap melakukan daur ulang dan merekrut tenaga-tenaga baru yang lebih berani untuk melakukan aksi teror (bom bunuh diri). ${ }^{2}$

Hasil jajak pendapat Litbang Kompas ${ }^{3}$ tentang "Jalan Memupus Radikalisme" menyimpulkan tumbuh suburnya gerakan radikalisme agama ini diakibatkan oleh beberapa faktor. Pertama, lemahnya penegakan hukum mencapai 28,0\%. Kedua, rendahnya tingkat pendidikan dan lapangan kerja mencapai $25,2 \%$. Ketiga, lemahnya pemahaman ideologi Pancasila mencapai 14,6\%. Keempat, kurangnya dialog antarumat beragama mencapai 13,9\%. Kelima, kurangnya pemahaman agama mencapai $4,9 \%$ dan Keenam, ketidakpuasan terhadap pemerintah mencapai 2,3\%. Sedangkan ketujuh, kesenjangan ekonomi mencapai 1,6\%. Kedelapan, lainnya mencapai 3,1\%. Kesembilan, tidak tahu/tidak jawab mencapai 6,4\%.

Berkaitan dengan itu, ibarat di musim penghujan benih-benih radikalisme, terorisme

2 Wakhid Sugiyarto, "Jihad di Mata para Terpidana Terorisme di Indonesia", Harmoni, Volume VIII, Nomor 32, Oktober-Desember 2009, h. 98-99

${ }^{3}$ Harian Umum Kompas edisi Senin 9 Mei 2011 tentang "Jalan Memupus Radikalisme" dengan mengajukan beberapa pertanyaan. "Menurut Anda, hal apa yang paling mendorong berkembangnya radikal bernuansa agama di Indonesia? Setuju atau tidakkah Anda dengan cara-cara yang dipakai kelompok radikal untuk mewujudkan keyakinannya? Menurut penilaian Anda memadai atau tidak pernan pemerintah mencegah terorisme?". 
dan aksi bom bunu diri tumbuh subur di kalangan anak muda. Dalam catatan intelijen Wawan Purwanto, dijelaskan bahwa pada tahun 2007, dua orang remaja yaitu Isa Anshori (16) dan Nur Fauzan (19) ditangkap Densus 88 karena diduga ikut terlibat dalam menyembunyikan Taufik Kondang, salah seorang anggota jaringan teroris komplotan Abu Dujana.

Tahun 2009 (17 Juli 2009) pelaku bom di JW Marriot adalah Dani Dwi Permana (18) dan Ritz Charlton Nana Ikhwan Maulana (28) Tahun 2011 (25 Januari 2011), Arga Wiratama (17), Joko Lelono, Nugroho Budi, Tri Budi Santoso, Yuda Anggoro. Roki Apris Dianto dibekuk oleh Densus 88 bersama ketujuh orang lainnya dalam kasus teror bom di wilayah Klaten, Sleman, dan Yogyakarta. ${ }^{4}$

Radikalisme yang menjurus pada intoleransi, ekstremisme dan kekerasan mengatasnamakan agama menjadi ancaman pada kehidupan masyarakat agama-agama dan negara-negara di dunia. Masyarakat, agama dan negera diharap mewaspadai radikalisme yang merusak harmoni masyarakat.

Radikalisme dan intoleransi merupakan paradoks yang muncul dalam massifnya globalisasi dan demokrasi. Globalisasi yang seharusnya menciptakan sikap dan pola pikir terbuka, justru direspon sebagian masyarakat agama dengan sikap takut sehingga malah memunculkan sikap penolakan atas realitas yang berbeda. Homogenitas menjadi landasan mereka dalam menciptakan harmoni. ${ }^{5}$

Artikel ini ditulis dengan tujuan agar kehidupan umat beragama dan manusia dapat hidup berdampingan, rukun, damai, harmonis dan menjunjung tinggi kasih sayang, bukan malah sebaliknya yang terus menebarkan

${ }^{4}$ Ada Yang Ditangkap, Ada Yang Jadi Pengantin, Laporan Khusus detikNews, 28 April 2011. Untuk informasi lebih rinci dapat dilihat pada buku Nugroho Wahyujatmiko (editor), Rentetan Peristiwa Bom di Indonesia (Jakarta: Yayasan Lazuardi Biru, 2012), h. 19-26.

${ }^{5}$ Tajuk Rencana Harian Umum Pikiran Rakyat edisi 17 November 2015. fitnah, kebencian dan menyelesaikan setiap persoalan dengan cara kekerasan.

Bila kita melihatnya dari kacamata agama (teologi, keyakinan), maka mengakarnya gerakan radikalisme (agama) Islam yang mewujud dalam aksi kekerasan, terorisme, bom bunuh diri yang bersumber dari teologi Hakimiyah dan doktrin Istisyhad (mati syahid) demi mendapatkan jaminan masuk surga yang dikelilingi 40 bidadari.

Pasalnya, mereka selalu menebarkan kebencian, permusuhan dengan memengang teguh pemahaman takfiri (pengkafiran) untuk menyelesaikan setiap perbedaan pendapat, keyakinan yang berujung pada cara main hakim sendiri, hingga menghilangkan nyawa orang lain sebagai tiket utama masuk surga.

Jika tindakan dan perilaku yang melukai aspek kemanusiaan dan hati nurani ini terus dilakukan secara sistematis, berkelanjutan oleh generasi muda, maka apa jadinya nasib bumi pertiwi. Tentunya, tidak menutup kemungkinan akan lahirnya Negara Islam Indonesia Malayasia. Tulisan ini akan menjelaskan jejak gerakan radikalisme yang disinyalir dari paham teologi Hakimiyah yang sudah mulai ada dan mengakar di Indoensia.

\section{Geneologi Radikalisme}

Pengasosiasian jihad dengan terorisme pada masa kini tak bisa lain disebabkan kenyataan, bahwa jihad dalam pengertian perang itu melibatkan elemen-elemen kekerasan yang dikategiriasiskan sebagai terorisme. Tetapi jelas, penggunaan kekerasan aats nama agama di masa kontemporer sebenarnya lebih banyak disebabkan faktorfaktor politik, yang kemudian dicirikan legitimasinya di dalam ajaran-ajaran agama. Tetapi, lagi-lagi harus hati-hati sebelum menyatakan kelompok-kelompok tertentu di kalangan Muslim, khususnya di Timur Tengah sebagai 'teroris' atau menjalankan 'terorisme', terutama dengan mempertimbangkan 
justifikasi atas tindakan dan aksi-aksi kekerasan yang mereka lakukan.

Dalam kaitan ini, agaknya menarik mengamati istilah yang digunakan beberapa pengamat dalam menyebut kelompok, organisasi atau bahkan negara yang sering dituduh pihak Barat sebagai 'teroris' atau menjelankan 'terorisme'. Sebaliknya, ia menggunakan istilah 'radikal' untuk menyebut mereka yang menjelankan tindakan-tindakan kekerasan.

Menurut sebagian pakar, penting untuk membedakan antara 'radikalisme' dengan 'terorisme.' Jika 'terorisme' hanya merupakan salah satu di antara berbagai instrumen kebijakan para pelakuknya, radikalisme adalah esensi dari kebijakan itu sendiri; radikalisme juga mencakup nilia-nilai, tujuan dan concern dari orang-orang yang merumuskan kebijakan itu. PLO di Palestina mungkin secara resmi meninggalkan 'terorisme' dalam keadaankeadaan tertentu dan sebaliknya menempuh perjuangan diplomatik, tetapi organisasi ini tak dapat meninggalkan radikalismenya. Karena meninggalkan radikalisme bagi PLO berarti meninggalkan tujuan bangsa Palestina mengubah status quo dan membangun, dengan jalan apapun, semacam negara Palestina. Adalah tujuan radikal ini yang paling ditakutkan Israel, bukan apa yang disebut sebagai ‘terorisme' PLO itu sendiri.

Di sini jelas bahwa radikalisme sebagai sikap jiwa yang membawa kepada tindakantindakan yang bertujuan melemahkan dan mengubah tatanan politik mapan dan biasanya dengan cara-cara kekerasan dan menggantinya dengan sistem baru. Lebih terinci lagi, istilah radikal mengacu pada gagasan dan tindakan kelompok yang bergerak untuk menumbangkan tatanan politik mapan; negara-negara atau rezim-rezim yang bertujuan melemahkan otoritas dan legitimasi negeranegara dan rezim-rezim lain; dan negara yang berusaha menyesuaikan atau mengubah

hubungan-hubungan kekuasaan yang ada dalam sistem internasional.

Istilah radikalisme, karenanya secara instrinsik berkaitan dengan konsep tentang perubahan politik dan sosial pada berbagai tingkatan. Dengan pengertian ini kita secara lebih pas dapat menempatkan berbagai kelompok atau organisasi dan negara-negara tertentu di Timur Tengah yang selama ini sering dipandang Barat sebagai 'teroris'. ${ }^{6}$

Secara genealogis,

Azra menggarisbawahi munculnya radikalisme agama berawal dari pemahaman agama yang cenderung skriptural-tekstualis, sempit, dan hitam putih. Pemahaman semacam ini dengan mudah akan menggiring pada keyakinan yang cenderung fundamentalis, bahkan sikap keagamaan yang kaku. Sedangkan fundamentalisme sendiri adalah spirit gerakan radikalisme agama yang mendorong penggunaan cara-cara kekerasan dalam memenuhi kepentingan dan tujuan mereka. Sehingga pada saat kondisi ekonomi, sosial, budaya, dan politik yang tidak menentu, tidak sedikit orang yang mengambil 'jalan pintas kekerasan' dengan mengatasnamakan agama ${ }^{7}$.

$$
\text { Radikalisme agama dapat pula }
$$
bersumber dari pembacaan yang salah terhadap sejarah agama yang dikombinasikan dengan idealisasi berlebihan terhadap doktrin agama pada masa tertentu. Ini terlihat dalam pandangan dan gerakan ortodoksi yang selalu eksis dihampir semua agama. Tema pokok dari sel ortodoksi ini adalah pemurnian agamamembersihkan agama dari pemahaman dan praktek keagamaan yang mereka pandang sebagai 'sesuatu yang menyimpang'. Namun upaya pemurnian tersebut justru acapkali dilakukan dengan cara-cara kekerasan. Dengan

6 Azyumardi Azra, "Jihad dan Terorisme: Konsep dan Perkembangan Historis”, Jurnal Islamika, Nomor 4, April-Juni 1994, h. 84-85.

${ }^{7}$ Nurudin, "Basis Nilai-Nilai Perdamaian: Sebuah Antitesis Radikalisme Agama di Kalangan Mahasiswa", Jurnal Multikultural \& Multireligius, Vol. 12 No. 3, September-December 2013, h. 65. 
pemahaman dan praksis keagamaan seperti itu, kelompok dan sel radikal ini 'menyempal' (splinter) dari mainstream agama yang memegang 'otoritas' teologis.

Radikalisme agama juga masuk melalui deprivasi politik, sosial dan ekonomi. Pada saat bersamaan, disorientasi dan dislokasi sosial budaya, ekses globalisasi, dan semacamnya menjadi tambahan faktor penting bagi kemunculan kelompok 'fundamentalis radikalis'. Kelompok ini tidak jarang mengambil bentuk kultus (cult), yang sangat eksklusif, tertutup dan berpusat pada seseorang yang dipandang kharismatik. Kelompok-kelompok ini dengan dogma eskatologis tertentu bahkan memandang dunia sudah menjelang akhir zaman dan kiamat; sehingga waktunya bertobat melalui pemimpin dan kelompok mereka.

Untuk itu, segala tindakan dan aksi radikalisme, terorisme ini erat kaitannya dengan pengalihan isu, konspirasi, kepentingan, pencitraan, sekelompok (kepercayaan, agama, etnis, ras, bangsa) tertentu terhadap segala kebijakan (politik) sebuah negara, bangsa.

Menurut Jean Baudrillard, dalam Nurudin, yang menarik dari aksi terorisme bukanlah kekerasannya, tetapi cara kekerasan ini dijadikan modal publikasi (social currency) lewat televisi, video, internet. Ini dilakukan dalam logika pencitraan. Ketidaktetapan (nomadn) pelaku (terduga) teroris di daerah (bangsa dan negara) tertentu ini sebagai upaya menghilangkan jejak sekaligus membuat jejaring yang terus tumbuh subur dan melakukan perlawanan terhadap segala sesuatu yang dianggap tidak adil ${ }^{8}$.

Konsep nomadisme merupakan sebuah konsep yang digunakan oleh Gillez Deveze dan Felix Gauttari, dalam Nurudin, untuk menjelaskan sebuah proses yang di dalamnya

8 Nurudin, "Basis Nilai-Nilai Perdamaian: Sebuah Antitesis Radikalisme Agama di Kalangan Mahasiswa...., h. 67. (sekelompok orang) tidak pernah menetap di teritorial tertentu tetapi selalu dalam proses perpindahan, transformasi terus menerus dari satu teritorial ke teritorial lain, sebagai proses deteritorialisasi. Dengan semakin mencairnya batas-batas global sebagai akibat dari proses globalisasi, peluang bagi setiap orang (termasuk para teroris) untuk menjalankan nomad strategy yang menjadi terbuka lebar-misalnya operasi teror yang berpindah dan bertransformasi dalam skala global yang menciptakan para teroris kosmopolitan: belajar teknologi elektronik di Jeman, sistem radar di Prancis, melakukan teror di Amerika Serikat, Indonesia, dalam percepatan perpindahan dan ketidakterdeteksian jejak-jejak perjalanannya?

Dalam menyikapi aksi terorisme ini terpaut dengan teori konspirasi karena berkaitan dengan fakta sejarah, keterlibatan AS dalam berbagai peristiwa teror global. Konspirasi dimungkinkan dalam politik, lantaran ruang politik (dan berbagai peristiwa di dalamnya) terbuka terhadap berbagai tafsiran.

Dengan demikian, terorisme adalah sebuah ruang dalam politik yang dapat digunakan sebagai medium pembuktian konspirasi. Teroris sangat terbuka bagi tafsiran konspiratif karena ia dapat menciptakan sebuah dunia realitas tanpa identitas (anomaly) yang terbuka bagi multi tafsir yang dapat dikaitkan dengan nama, kelompok, lembaga (fraksi) apa saja.

Lewat sebuah aksi bom dapat diciptakan pengelabuan informasi (deception) dan pengelabuan realitas (byper reality) lantaran ia bisa diatur dari satu tempat umum yang dengan segera menimbulkan konotasi, kecurigaan dan tuduhan (fitnah) pada satu pihak (kelompok). Misalnya, peledakan gereja yang langsung berkonotasi teror Islam; ledakan daerah turis (Bali) yang langsung berkonotasi

\footnotetext{
${ }^{9}$ Nurudin, "Basis Nilai-Nilai Perdamaian: Sebuah Antitesis Radikalisme Agama di Kalangan Mahasiswa...., h. 67.
} 
teroris anti Amerika. Dengan demikian, ia dapat menggiring ke arah sebuah sistem fitnah terbuka, sehingga siapa saja bisa dituduh dan difitnah sebagai pelaku. Padahal boleh jadi sang penuduh itulah pelaku yang sesungguhnya.

Dari sini kita dapat membedakan nalar teroris sejati (true terrorist) yang menyebarkan kekerasan sambil menyatakan bahwa dirinya yang bertanggung jawab dengan teroris virtual yang melakukan peledakan bom, tetapi dengan menggunakan tangan-tangan orang bayaran yang bertindak seolah-olah (as if); seolah-olah sebagai anggota kelompok tertentu (seperti AlQaeda); seolah-olah beragama tertentu dengan pakaian tersendiri; seolah-olah dari bangsa tertentu (seperti Palestina) dengan menggunakan nama tersendiri. Mereka selalu berlindung di balik topeng-topeng, di balik kambing hitam dengan memproduksi terorteror palsu (simulacrum of terror).

Memang terorisme merupakan bagian yang tidak dapat dipisahkan dari strategi perang. Terorisme tidak bisa dipisahkan dari strategi efek-efek ketakutan, panik dan trauma pada musuh dan masyarakat secara umum untuk kepentingan politik pihak-pihak tertentu.

Teror, dengan demikian dapat dilakukan atas nama agama mana pun (IRA atas nama Kristen, Al-Qaeda atas nama Islam); atas negara mana pun (Libanon, Irak, India, Libia); atas nama etnis mana pun (Aceh, Ambon, Papua); atas nama ras mana pun (kulit putih, hitam); atas nama bangsa mana pun (Arab, Sikh, Kurdi, Tamil, Irlandia). Artinya teror Islam (teros atas nama Islam) secara prinsip juga dimungkinkan terjadi, khususnya ketika kepentingan agama berbaur dengan kepentingan politik.

Simulasi teror, sebagaimana dikatakan Baudrillard adalah sebuah bentuk politik realitas, yakni sebuah cara mempermainkan realitas, psikologi massa, citra, opini publik untuk kepentingan politik tertentu. Di dalamnya bisa saja diciptakan sebuah aksi teror yang tampak nyata, yang dilakukan oleh sekelompok teroris yang tampak nyata, dengan kuasalitas yang yang juga tampak nyata (ada markas, tempat latihan). Padahal, semuanya dilakukan oleh aktor-aktor yang berperan seakan-akan. Ini nampaknya tidak masuk akal. Tetapi beberapa peristiwa teror di Timur Tengah, Amerika Tengah, Indonesia pada era Orde Baru menunjukkan bahwa simulasi itu tengah berlangsung. ${ }^{10}$

Jika kita merunut akar dari radikalisme ini disebabkan; Pertama, tekanan politik penguasa. Munculnya sebagai akibat otoriterisme. Dalam kasus Orde Baru, negara selalu membabat habis yang diidentifikasi sebagai gerakan radikal. Baginya, radikalisme adalah musuh nomor satu dan dijadikan sebagai musuh bersama (common enemy) melalui berbagai media transformasi. Kedua, kegagalan rezim sekular dalam merumuskan kebijakan dan mengimplementasikannya di dalam kehidupan masyarakat. Ketidakpastian ekonomi dunia, ketidakpercayaan dan kegagalan atas pembangunan. Ketiga, respons terhadap Barat. Kebanyakan isu yang diangkat ke permukaan oleh kelompok ini apapun yang datangnya dari barat terlarang. Keempat, rasionalisasi yang menghasilkan modernisme dan kapitalisme. Sebagai anak kandung rasionalisasi, modernisasi akan dapat menggerogoti pilar-pilar agama yang disebabkan oleh cara berpikir yang bertolak belakang.

Kelima, secara politis umat Islam di dunia internasional berada dalam kawasan pinggiran. Umat Islam sering diadu domba dengan kebijakan-kebijakan politik yang dilakukan oleh negara-negara adi daya (Amerika, Inggris dan sekutunya). Keenam, serangan kultur (budaya) terhadap masyarakat Islam. Dengan tingkat kebudayaan dan teknologi canggih

10 Yasraf Amir Piliang, Bayang-Bayang TubanAgama dan Imajinasi (Bandung: Mizan, 2011), h. 99-104 dan 108-109. 
dunia modern ini melakukan penetrasi budaya yang terjadi secara deras, maka dapat dipastikan budaya Islam menjadi terpinggirkan. Ketujuh, kegagalan negara-negara dengan mayoritas penduduk beragama Islam dalam menyejahterakan masyarakat menjadi variabel penting munculnya gerakan ini. ${ }^{11}$

Untuk mencapai tujuan politis terkadang tindakan kekerasan dapat dianggap suatu kebaikan. Justru dengan adanya asumsi penggunaan tindakan kekerasan merupakan salah satu metode pencapaian tujuan luhur, maka tidak aneh jika naluri agresif manusia terkadang tumbuh subur di bawah naungan agama. Padahal pada dasarnya tujuan akhir dari semua agama (ideologi) supaya meringankan kesengsaraan manusia. Dengan demikian penggunaan kekerasan untuk mencapai tujuan mulia itu sama sekali tidak dapat dibenarkan dengan dalih apapun.

Radikalisme agama dalam dunia politik terus terjadi. Parahnya, pelaku kekerasan pada umumnya didorong atas keyakinan keagamaan. Pasalnya apa yang mereka lakukan sejalan dengan perintah Tuhan yang tercantum dalam teks-teks suci.

Kekerasan atas nama agama tetap sulit dibendung. Tercatat beberapa tindakan kekerasan yang disulut oleh kelompok keagamaan yang ekstrim. Takfir wal Hijrah di Mesir yang bertanggung jawab atas pembunuhan Anwar Sadat tahun 1981. Pembunuhan terhadap Indira Gandhi, Perdana Menteri India pada tahun 1984 oleh dua bodyguardnya sendiri dari kelompok sirkh yang tergugah untuk membalas dendam terhadap kebijakan politik Indira yang dinilai merugikan kaum Sirkh dan didorong motivasi keagamaan $^{12}$.

${ }^{11}$ Nur Syam, Tantangan Multikulturalisme Indonesia: Dari Radikalisme Menuju Kebangsaan (Jogyakarta: Kanisius-Impulse, 2009), h.124-128.

${ }^{12}$ Ansyaad Mbai, Dinamika Baru Jejaring Teror di Indonesia (Jakarta: Squad Publishing, 2014), h. 22-23.
Paul Hill, pemuka agama dari gereja Presbiterian di Amerika Serikat tidak hanya mengajarkan penggunaan kekerasan terhadap mereka yang melanggar ajaran agama tentang aborsi. Mereka membunuh dokter yang melakukan aborsi terhadap pasiennya. Pendeta David C. Trosch dari Katolik menyatakan membunuh dokter yang melakukan praktek aborsi merupakan tindakan pembunuhan yang sah.

Rabbi Shiamo Goren, mantan pemimpin Rabbi Yahudi untuk kelompok Ashkenazic (Yahudi Eropa Barat) di Israel berfatwa pembunuhan atas diri Yasser Arafat merupakan bagian dari salah satu tugas suci keagamaan. Pembunuhan Yatzhak Rabin, Perdana Israel menjadi bentuk nyata dari satu tindakan kekrasan yang berujung di bawah panji-panji agama. Dengan tegar pembunuh Rabin, Yigal Amir berkata ia melakukannya atas perintah agama dan atas bantuan Tuhan. "Ini merupakan Tuhan keagamaan saya yang sesuai dengan ajaran balakha (hukum agama Yahudi)"13.

Di Indonesia, apa yang diharapkan dari pemuka agama tidak lain adalah mecegah timbulnya penafsiran-penafsiran keagamaan yang dapat mencegah ke arah radikalisme dan kekerasan. Dalam lingkungan Islam, di atas pundak pemuka agama terletak kewajiban untuk mensosialisaikan konsep moderasi guna menciptakan masyarakat penengah dan adil "ummatan wasathan." ${ }^{14}$

Ihwal maraknya aksi terorisme di Indonesia ini termasuk dalam tipe teroris yang dimasuki oleh agama (religiously motivated). Para terorisme di Indonesia adalah penganut Islam radikal yang bertujuan mendirikan negara Islam di Indonesia melalui jalan kekerasan. Adicita para terorisme bisa dibaca di pelbagai

\footnotetext{
13 Ansyaad Mbai, Dinamika Baru Jejaring Teror di Indonesia............, h. 22-23.

14 Alwi Shihab, Islam Inklusif: Menuju Sikap Terbuka Dalam Beragama (Bandung: Mizan-AN Teve,1997), h. 146-149
} 
buku-buku radikal seperti karya Abu Bakar Ba'asyir yang berjudul Tarkiroh 1 dan $I I .{ }^{15}$

Tampaknya Indonesia lebih banyak memilih cara-cara kekerasan ketimbang dengan cara berdialog, negosiasi, kompromi lainya sebagai bagian terpenting dari demokrasi. Semua bentuk kekerasan yang dilakukan oleh umat beragama (Islam) sebenarnya tidak menjadikan semakin mulianya suatu agama, tapi malah sebaliknya, semakin mengkerdilkan agama. Agama menjadi terpasung karena hanya dibungkus dalam tafsir kekerasan. Padahal kita tahu kekerasan bukanlah diajarkan oleh setiap agama, sebab sejatinya semua agama adalah rahmat bagi umat manusia.

Sungguh berbahaya ketika agama ditafsirkan sebagai "jalan kekerasan' sebab yang tampak di mata umat beragama adalah semua yang berbeda dengan kelompoknya senantiasa akan dianggap musuh yang harus dilenyapkan. Pembumihangusan mereka ditafsirkan pula sebagai usaha melenyapkan "musuh agama" yang akan berbuah tiket menuju surga. ${ }^{16}$

Bagi para pakar, maraknya aksi terorisme, radikalisme, fundameltalisme ini disebabkan ketidakberdayaan agama menghadapi tantangan industri dan globalisasi sekaligus tercerabutnya unsur keibuan (cinta, kasih sayang, tolong menolong) pada agama diakibatkan dari ganasnya arus modernitas.

Biasanya para penganut radikal ini memiliki watak hitam-putih, non-kompromi, dan cenderung menolak kebenaran dari pihak lain; sesudah cita-cita untuk menjadikan Islam sebagai dasar negara mengalami kegagalan; mengalami kekecewaan, kegagalan dan frustrasi akibat perkembangan sosio-politik yang membuat mereka termarginalkan;

\footnotetext{
15 Ansyaad Mbai, Dinamika Baru Jejaring Teror di Indonesia............., h. 22-23.

16 Zuly Qadar, Gerakan Sosial Islam: Manifesto Gerakan Kaum Beriman (Jogyakarta: Pustaka Pelajar, 2009), h. 8-9.
}

kesenjangan ekonomi, hukum; ketidaksiapan sebagian anggota masyarakat untuk mengikuti perubahan zaman (globalisasi dan industrinisasi) semakin cepat terjadi; bacaan buku-buku karya Maududi, Quthb, M. Albahi, Al-Ghazali. Ini semua dapat membangkitkan perasaan benci, permusuhan terhadap Barat dengan segala produknya (kapitalis).

Pada dasarnya yang melahirkan kekerasan adalah rantai-rantai peradaban. Alihalih melahirkan perdamaian dan memeratakan keadilan, industrialisasi dan globalisasi justru menciptakan kekerasan dan penindasan. Persaingan akan mendorong pihak yang lemah untuk mempertahankan diri, dan jika keadilan tetap tidak dapat diwujudkan dengan cara damai, maka kekerasan pun akan muncul. Walhasil yang sebenarnya menciptakan kekerasan adalah ketidakadilan itu sendiri yang mewujud dalam bentuk lain. ${ }^{17}$

Mengenai aksi teror bom bunuh diri telah berlangsung sejak tahun 1980an. Robert A. Pape berbicara mengenai logika startegis, sosial dan individual dari pelaku bom bunuh diri. "Kasus teror bunuh diri sejak tahun 19802003, menunjukkan secara umum mereka lebih kecil dibandingkan dengan para musuhnya; komunitas nasional tertentu mendukung secara luas tujuan (taktik) politiknya; kaum militan memiliki ikatan kesetiaan yang erat dengan rekannya dan devosi kepada pemimpin; dan mereka memiliki sisten inisiasi dan ritual yang menyimbolkan tingkat komitmen individu pada komunitas.

Kelompok teroris bunuh diri modern boleh jadi menerima bantuan material aspirasi politik seperti mereka, namun mereka pelaku independen yang jarang mengikuti petunjuk dari yang lain secara membabi buta. Yang mungkin terpenting, aksi bunuh diri modern mematikan sekali karena tujuan penyerang

17 Afif Muhammad, Agama dan Konflik Sosial: Studi Pengalaman Indonesia (Bandung: Marja, 2013), h. 3235. 
bukan hanya untuk mati, tetapi menggunakan kematiannya untuk membunuh sebanyak mungkin target korban.”18

Dalam sejarah peradaban umat manusia, radikalisme agama pada umumnya berujung pada atau dengan kegagalan. Apalagi jika filosofi yang digunakan adalah kebencian dan fanatisme. Pendukung radikalisme agama tampaknya tidak mempunyai modal untuk menawarkan perdamaian dan kesejahteraan. Napas yang sesak karena berbagai hantaman sejarah yang datang bertubi-tubi telah menempatkan sebagian Muslim dalam posisi tragis tetapi tak berdaya. Oleh sebab itu mereka menempuh jalan pintas berupa selfdefeanting (menghancurkan diri sendiri) atas nama agama yang dipahami dalam suasana jiwa yang sangat rentan dan tertekan.

Radikalisme dalam jangka panjang hanyalah akan menjadi iklan yang buruk bagi agama yang dinilai suci oleh para penganutnya. Umat Islam adalah di antara yang paling rentan terhadap godaan radikalisme karena posisi mereka yang masih berada di puritan peradaban. Posisi puritan dapat mendorong orang untuk menempuh jalan pintas dalam mencapai tujuan, tetapi dalam jangka panjang pasti akan berujung pada penderitaan, penyesalan dan kegagalan, yang paling repot. Kadang-kadang umat Islam dituntut untuk memerangi terorisme, tetapi pada saat yang sama sekaligus dituduh sebagai terorisme. ${ }^{19}$

\section{Anak Muda}

Berkenaan dengan aksi, tindakan radikalisme kaum muda ini merupakan salah satu fenomena penting dan menarik yang bercorak lintas-bangsa, lintas-budaya dan lintas-sejarah. Kita bisa memulai cerita dari seberang lautan, dengan menengok rangkaian

18 Mutiara Andalas, Politik Para Teroris, (Yogyakarta: Kanisius, 2010), h. 43

19 Ahmad Syafii Maarif, "Islam dan Bahaya Radikalisme Beragama," dalam kata pengantar buku Pray to Kill, M Haniff Hassan, Jakarta: Grafindo Khazanah Ilmu, 2006), h. XV-XXII. peristiwa yang belum lama terjadi di kawasan Timur-Tengah atau di jazirah Arabia: terjadinya gelombang besar demokratisasi yang mengharu-biru negeri-negeri yang melahirkan para nabi tersebut.

Bermula dari Tunisia, bersambung ke Mesir, berlanjut di Libya, dan mungkin masih berlanjut ke negara-negara lainnya, bergiliran kekuasaan otoriter oleng dan tumbang digerus oleh gelombang tuntutan perubahan dan pembaruan. Di balik rangkaian peristiwa dramatis yang belakangan acap disebut sebagai "musim semi Arab" the Arab's spring tersebut, kita mendapati peran kunci kaum muda dalam menggalang dan menghembuskan gelombang topan yang berujung pada kejatuhan rezimrezim tiran tersebut. Dengan demikian, kita menemukan kaum muda berada di garis depan gerakan perlawanan terhadap rezim-rezim otoriter yang selama beberapa dasawarsa terakhir mengangkangi rakyat di berbagai negeri di Timur-Tengah.

Secara empirik, maraknya gerakan sosial radikal di kalangan kaum muda Islam sejak beberapa tahun terakhir ini membetot perhatian besar dari khalayak luas, baik dari kalangan akademisi, masyarakat sipil, media maupun pengambil kebijakan serta memunculkan banyak pertanyaan penting. $\mathrm{Hal}$ ini terutama ketika sebagian dari mereka memilih bentuk aksi kekerasan, baik terorisme maupun vigilantisme, sebagai pola artikulasi radikalisme sosial dan politik mereka. ${ }^{20}$

Dengan adanya keikutsertaan 16 WNI yang ditangkap otoritas Turki saat hendak menyeberang ke Suriah tanpa dokumen yang lengkap; beredarnya video berjudul "Cahaya Tarbiyah di Bumi Khilafah"; diunggahnya foto bertuliskan "Anshar Khilafah Islamiyah from Ciwalen Garut West Java Indonesia" yang diduga diambil di kawasan Gunung

${ }^{20}$ Muhammad Najib Azca, "Yang Muda, Yang Radikal; Refleksi Sosiologis Terhadap Fenomena Radikalisme Kaum Muda Muslim di Indonesia Pasca Orde Baru”, Maarif, Vol. 8, No. 1, Juli 2013, h. 14-17. 
Papandayan, Kecamatan Cisurupan Garut ini menjadi bukti nyata atas (masih) suburnya benih-benih radikal yang ditanam di kalangan anak-anak, pemuda untuk menegakkan negara Islam sebagai solusi hidup atas melemahnya penegakan hukum, kesenjangan kesejahteraan, ketidakadilan yang terus mendera Indonesia.

Hasil penelitian Lembaga Kajian Islam dan Perdamaian (LaKIP) tentang radikalisme di kalangan pelajar se-Jabodetabek menunjukkan hampir 50 persen pelajar menyetujui tindakan radikal atas nama agama. Beberapa pengamat terorisme dan intelijen melihat reaksi kaum muda tersebut sebagai benih-benih pemikiran yang bisa mengarah pada tindakan terorisme.

Munculnya pelaku teroris, bom bunuh diri dari kalangan pelajar, mahasiswa, dan pemuda yang berusia di bawah 30 tahun menunjukan adanya kegagalan Pendidikan Agama Islam (PAI) dalam menumbuhkan sikap kebhinekaan siswa sehingga tingkat persetujuan atas aksi radikal tinggi, mencapai 48,9 persen.

Wilayah Jabodetabek yang menjadi sampelnya. Ihwal radikalisme dan toleransi Muslim terhadap non-Muslim (Oktober 2010Januari 2011) dengan responden 590 guru dari 1.639 guru pendidikan agama Islam dan 993 siswa (sekolah menengah pertama kelas VIII dan IX serta sekolah menengah atas semua kelas) dari 611.678 siswa menunjukkan hasil yang membenarkan besarnya kecenderungan radikal dan intoleran.

Dalam kasus radikalisme, misalnya, untuk tingkat pengenalan dan kesetujuan terhadap organisasi radikal, rata-rata persentase guru dan siswa masing-masing 66,4 persen dan 26,7 persen (pengenalan) serta 23,6 persen dan 12,1 persen (kesetujuan). Untuk tingkat pengenalan dan kesetujuan terhadap tokoh-tokoh radikal, rata-rata persentase guru dan siswa: 69,2 persen dan 26,6 persen (pengenalan) serta 23,8 persen dan 13,4 persen (kesetujuan). Dari temuan Lakip itu, jelas sekali guru dan siswa di Jabodetabek mengenal organisasi dan tokoh radikal serta sebagian dari mereka menyetujui tindakan organisasi dan tokoh tersebut.

Radikalisme erat kaitannya dengan sikap intoleransi. Betapa tidak, laporan survei Lakip menunjukan; 62,7 persen guru dan 40,7 persen siswa menolak berdirinya tempat ibadah nonIslam di lingkungan mereka. Guru (57,1 persen) dan siswa (36,9 persen) juga menolak bertoleransi dalam perayaan keagamaan di lingkungan mereka. Lebih jauh lagi, dari hasil survei itu juga ditemukan fakta yang menarik: 21,1 persen guru dan 25,8 persen siswa menganggap Pancasila tidak lagi relevan sebagai ideologi negara. Guru dan siswa pun menganggap persoalan bangsa akan teratasi bila syariat Islam diterapkan di Indonesia (65 persen). ${ }^{21}$

Padahal keberadaan pemuda hari ini, merupakan pemimpin masa depan. Apa jadinya bila penerus estafeta kepemimpinan, pengisi pembangunan bangsanya sudah kehilangan jati dirinya, bahkan akrab dengan cara-cara kekerasan untuk mencapai tujuannya. Sejatinya, generasi muda harus tampil menjadi ujung tombak perjuangan tombak dalam pencerdasan suatu kehidupan bangsa dan negara melaui cara-cara yang baik.

Bagi Martin van Bruinessen ${ }^{22}$, timbulnya pemahaman agama yang radikal di kalangan anak muda sebetulnya wajar dan sendirinya bukan sesuatu yang dikhawatirkan. Sebuah umat yang hanya terdiri dari satu ortodoksi yang monolitik mudah kehilangan dinamika dan semangat hidup.

Dalam sejarah gereja di dunia Barat sekte-sekte radikal sering telah berfungsi sebagai hati nurani umat, dapat dilihat di sejarah umat Islam. Gerakan sempalan radikal 2011.

${ }^{21}$ Harian Umum Koran Tempo, edisi 29 April

22 Martin van Bruinessen, "Gerakan Sempalan di Kalangan Umat Islam Indonesia: Latar Belakang SosioBudaya", Ulumul Quran, Volume III No I Tahun 1992, h. 25 . 
mendorong ortodoksi untuk setiap saat memikirkan kembali relevansi ajaran agama dalam masyarakat kontemporer dan untuk menjawab atas masalah dan tantangan baru yang terus timbul.

Baru muncul bahaya kalau komunikasi antar ortodoksi dan gerakan sempalan terputus dan mereka terasingkan karena kurang pengalaman hidup, pengetahuan agama, mereka dengan sangat mudah bisa dimanipulasi (diarahkan) kepada kegiatan yang tidak sesuai dengan kepentingan umat.

Sebagai akibat urbanisasi dan moneterisasi ekonomi banyak ikatan sosial yang tradisional semakin longgar (terputus). Dalam desa tradisional, setiap orang adalah angggota sebuah komunitas cukup intim dengan kontrol sosial yang tetat, tetapi dengan sistem perlindungan dan jaminan sosial. Jaringan keluarga yang luas melibatkan setiap individu dalam sebuah sisitem hak dan kewajiban yang sampai batas tertentu kesejahteraannya.

Pada masyarakat kota modern sebaliknya, setiap orang berhubungan dengan jauh lebih banyak orang lain, tetapi hubungan ini sangat dangkal dan tidak mendorong tanggungjawab yang berarti. Dalam suasana ini, aliran agama sering bisa memenuhi kekosongan yang telah terjadi karena menghilangkanya komunitas keluarga besar dan desa. Namun, untuk dapat berfungsi sebagai komunitas aliran ini mestinya bisa saling mengenal karena cukup kecil anggotanya. Aspek komunitas dan solidaritas antara sesama anggota diperkuat lagi kalau aliran ini membedakan diri dengan tajam dari dunia sekitarnya.

Menurut Muhammad Najib Azca, setidaknya ada 3 faktor yang bisa digunakan untuk menjelaskan fenomena radikalisme di kalangan kaum muda. Pertama, dinamika sosial politik di fase awal transisi menuju demokrasi yang membuka struktur kesempatan politik (political opportunity structure) yang baru di tengah tingginya gejolak dan ketidakpastian. Kedua, transformasi gerakan radikal Islam yang sebagian memiliki geneologi pada awal kemerdekaan. Ketiga, tingginya angka pengangguran di kalangan kaum muda di Indonesia. Ketiga faktor itulah yang berjalan berkelindan bersama faktor lain sehingga menyebakan radikalisme mendapat tempat yang subur di kalangan generasi muda. ${ }^{23}$

Radikalisme memang tidak persis sama dan tidak bisa disamakan dengan terorisme. Ahmad Syafii Maarif pernah menyatakan bahwa radikalisme lebih terkait dengan model sikap dan cara pengungkapan keberagamaan seseorang, sedangkan terorisme secara jelas mencakup tindakan kriminal untuk tujuantujuan politik. Radikalisme lebih terkait dengan problem intern keagamaan, sedangkan terorisme adalah fenomena global yang memerlukan tindakan global juga. Namun radikalisme kadang-kala bisa berubah menjadi terorisme, meskipun tidak semuanya dan selamanya begitu. ${ }^{24}$

Bagi Ahmad Syafii Maarif, menuturkan maraknya aksi tetorisme yang melibatkan sekelompok (kalangan muda) amat kecil Muslim harus dibaca dari kacamata ketidakberdayaan (keputusasaan) dalam menghadapi realitas dan kekinian yang mereka rasakan sangat kelam dan menghimpit. ${ }^{25}$

Dengan demikian, radikalisme adalah fanatik kepada satu pendapat serta menegasikan pendapat orang lain, abai terhadap historisitas Islam, tidak dialogis, dan harfiah memahami teks agama tanpa mempertimbangkan tujuan esensial syariat (maqsid al-syariat).

23 Azca, Muhammad Najib, "Yang Muda, Yang Radikal; Refleksi Sosiologis Terhadap Fenomena Radikalisme Kaum Muda Muslim di Indonesia Pasca Orde Baru”, Maarif, Vol. 8, No. 1, Juli 2013, h. 24.

${ }^{24}$ Ahmad Fuad Fanani, "Fenomena Radikalisme di Kalangan Kaum Muda", Maarif, Vol. 8, No. 1, Juli 2013, h. 7-8.

${ }^{25}$ Ahmad Syafii Maarif, Menerobos Kemelut: Refleksi Cendekiawan Muslim Jakarta, Grafindo Khazanah Ilmu,2005), h. 56. 
Ciri-ciri kelompok radikal: Pertama, acap mengklaim kebenaran tunggal dan menyesatkan kelompok lain yang tak sependapat dengan mereka. Klaim kebenaran selalu muncul dari kalangan yang seakan-akan mereka adalah Nabi yang tak pernah melakukan kesalahan-kesalahan. Padahal mereka hanya manusia biasa. Kedua, radikalisme seakan-akan mempersulit agama dengan menganggap ibadah sunnah seakanakan wajib dan yang makruh seakan-akan haram. Contohnya fenomena memanjangkan jenggot, meninggikan celana di atas mata kaki. Ketiga, kelompok radikal kebanyakan mengalami over dosis agama yang tidak pada tempatnya. Dalam berdakwah, mereka mengesampingkan metode gradual yang digunakan Nabi, sehingga dakwah mereka justru membuat umat Islam yang masih awam merasa ketakutan dan keberatan. Keempat, kasar dalam berinteraksi, keras dalam berbicara, dan emosional dalam berdakwah. Ciri dakwahnya sangat bertolak belakang dengan kesantunan, kelembutan berdakwah Nabi.

Kelima, kelompok radikal mudah berburuk sangka kepada orang lain di luar golongannya. Mereka senantiasa memandang orang lain hanya dari segi negatifnya dan mengabaikan aspek positifnya. Keenam, mudah mengkafirkan orang lain yang berbeda pendapat. Pada masa klasik, sikap seperti ini identik dengan golongan khawarij. Kini identik dengan Jamaah Takfir wa al-Hijrah. Kelompok terakhir ini mengkafirkan orang lain yang berbuat maksiat, mengkafirkan pemerintah yang menganut demokrasi, mengkafirkan rakyat yang rela terhadap penerapan demokrasi, mengkafirkan ulama yang tak mengkafirkan pemerintah demokratis dan mengkafirkan semua orang yang mengkritik pandangan mereka, sebab mereka yakin pendapat mereka adalah pendapat Allah.

Faktor kemunculan radikalisme; Pertama, pengetahuan agama yang setengah-setengah melalui proses belajar yang doktriner. Kedua, tekstual dalam memahami teks-teks agama, sehingga kalangan radikal hanya memahami Islam dari kulitnya saja, tapi miskin wawasan tentang esensi agama. Ketiga, tersibukkan oleh masalah-masalah sekunder dan partikular seperti menggerak-gerakan jari ketika tasyahud, memanjangkan jenggot, dan meninggikan celana sembari melupakan masalah-masalah primer. Keempat, over dosis dalam mengharamkan banyak hal yang justru memberatkan umat. Kelima, lemah dalam wawasan sejarah dan sosilogi sehingga fatwafatwa mereka sering bertentangan dengan kemaslahatan umat dan akal sehat. Keenam, radikalisme tidak jarang muncul sebagai reaksi terhadap bentuk-bentuk radikalisme lain, seperti sikap radikal kaum sekular yang menolak agama. Ketujuh, perlawanan terhadap ketidakadilan sosial, ekonomi, dan politik di tengah-tengah masyarakat.

Radikalisme tidak jarang muncul sebagai ekspresi rasa frustasi, pemberontakan terhadap ketidakadilan sosial yang disebabkan oleh mandulnya kinerja lembaga hukum. Kegagalan pemerintah dalam menegakkan keadilan, akhirnya direspons oleh kalangan radikal dengan tuntutan penerapan syariat Islam. Dengan menerapkan aturan syariat, mereka merasa dapat memenuhi perintah agama dalam rangka menegakkan keadilan. Namun, tuntutan penerapan syariah sehingga diabaikan oleh negara-negara sekuler, sehingga mereka frustasi dan akhirnya memilih cara-cara kekerasan.

Al-Qaradawi berupaya menawarkan solusi yang harus ditempuh guna mengatasi masalah radikalisme; Pertama, menghormati aspirasi kalangan Islamis melalui cara-cara yang demokratis. Kedua, memperlakukan mereka secara manusiawi dan penuh persaudaraan. Ketiga, tidak melawan mereka dengan sikap yang sama-sama ekstrem dan radikal. Kalangan radikal ekstrim dan sekuler ekstrem harus ditarik ke posisi moderat agar 
berbagai kepentingan dapat dikompromikan. Keempat, dibutuhkan masyarakat yang memberi kebebasan berpikir bagi semua kelompok, sehingga akan terwujud dialog sehat dan saling mengkritik antar isme-isme secara simpatik. Kelima, menjauhi sikap saling mengkafirkan dan tidak membalas pengkafiran dengan pengkafiran.

Keenam, mempelajari agama secara benar sesuai dengan metode-metode yang sudah ditentukan oleh para ulama Islam dan mendalami esensi agama agar menjadi muslim yang bijaksana. Ketujuh, tidak memahami Islam secara parsial, reduktif. Caranya dengan mempelajari esensi tujuan syariat. Dengan mengamalkan esensinya, umat Islam tidak akan terkait pada hal-hal yang bersifat simbolik. Artibut jubah dan celana di atas mata kaki adalah contoh pemahaman agama yang simbolis. Sejatinya, Nabi tidak pernah menentukan jenis-jenis pakaian, tetapi Nabi memakai berbagai model pakaian yang simpel dan fleksibel. Kedelapan, sebaiknya kalangan radikal lebih mempertimbangkan kondisi, situasi dan kemampuan Muslimin yang sangat beragam. Tidak bijaksana apabila kalarang radikal memaksakan kehendaknya tanpa mempertimbangkan kelemahan dan rintangan yang dihadapi oleh kaum Muslimin pada umumnya. Kesembilan, seyogyanya kalangan radikal memahami urutan perintah dan larangan yang harus diprioritaskan untuk dikerjakan (dijauhi, ditinggalkan). Kesepuluh, kalangan radikal seyogyanya memegang prinsip, perbedaan dalam masalah ijtihad adalah keniscayaan, sehingga mereka tidak terjebak dalam klaim kebenaran tunggal.

Saking pentingnya usaha damai dalam mengurai sikap radikalisme di kalangan pemuda, Al-Qaradawi berpesan "Saya mendorong para pemuda agar bersikap moderat, bijaksana dan menjauhi radikalisme." ${ }^{26}$

${ }^{26}$ Irwan Masduqi, Berislam Secara Toleran: Teologi Kerukunan Beragama (Bandung: Mizan, 2011), h. 119-122.

\section{Doktrin Istisyhad}

Isu terorisme erat kaitannya dengan gagasan ideologis dan teologis penganut Wahabi dan al-Qaeda melalui aksi bom syahidnya. Pelaku kekerasan dan pengeboman mati syahid menyakini segala tindakan ini sebagai bukti nyata atas tindakan syahid yang akan diganjar surga dan disambut malaikat dengan 40 bidadarinya.

Doktrin mencari mati syahid (istisybad) antara lain melalui bom bunuh diri itu memperoleh tempat bersemai dan habitatnya untuk menegakan gagasan khalifah global (Daulab Islamiyah), di tingkat lokal bersinergi dengan gerakan Daru Islam (NII) yang tidak lenyap dalam dinamika politik nasional. Pada doktrin global dibagi dua secara diametral; (hitam-putih), antara daarus-salam di satu sisi yang menjadikan syariat sebagai referensi utama dan daarul harb yang menuntut penganut syahidisme dikuasai oleh peradaban Barat.

Dalam pemahaman lebih moderat, jihad tidak hanya bisa diartikan sebagai perang melawan kekafiran, tetapi jihad adalah usaha yang sungguh-sungguh dengan segenap kemampuan untuk mencapai tujuan yang luhur di jalan Allah. Jihad dapat dilakukan dengan bekerja keras melawan hawa nafsu yang menghancurkan dan menjerumuskan manusia kepada kebinasaan. Jihad dalam bentuk perang diizinkan oleh Allah demi menjaga kehormatan, harta dan martabat manusia dan kaum muslimin. ${ }^{27}$

Namun, bagi syahidisme seperti Imam Samudra pengebom WTC adalah istisyhad (tindakan mencari kesyahidan). Imam Samudra menuliskan "Pembatasan bom syahid hanya boleh di Palestina, atau yang semisal menunjukkan bahwa Yusuf Qardhawi kurang memahami (menyadari) hakikat perang salib yang bersifat global. Di mana, dalam keadaan umat Islam terjajah, setiap jengkal tanah di

27 Nasir Abas, Membongkar Jamaah Islamiyah : Pengakuan Mantan Anggota JI, (Jakarta: Grafindo Khazanah Ilmu, 2009), h. 27 
bumi ini dapat dikatakan sebagai tempat konflik. Dengan sendirinya, segala syarat perang dalam Islam dapat diaplikasikan sesuai dengan kemampuan dan kemungkinan yang ada. Dalam menghadapi perang Salib, alQaeda telah beberapa kali mengadakan istisybad global (amaliyah)." 28

Aksi bom bunuh diri ini didasarkan pada prinsip tauhid yang menurut penganutnya bisa mempersatukan kaum Muslimin di seluruh dunia. Suatu doktrin yanag menjadi pusat perhatian Wahabi dalam menyebarkan pengaruhnya di dunia Islam. Dari sini, doktrin mati syahid menjadi bermakna, sehingga memiliki daya panggil paling manjur bagi anakanak muda Muslim di seluruh dunia (Indonesia).

Yusuf Qardhawi yang menyatakan mati syahid hanya bisa diperoleh di medan perang, seperti Palestina ditolak para pelaku teror. Pasalnya, pelaku istisyhad, zaman sekarang ini adalah Perang Salib terbuka tahap ke-10. Atas alasan itu, syahid bisa dicapai di mana pun saja sepanjang memerangi kaum kafir yang diwakili Amerika dan antek-anteknya.

"Operasi tempur istisybad, baik menggunakan bom atau tidak jelas memiliki latar belakang dan motivasi yang berbeda. Sama sekali tidak ada hubunganya dengan bunuh diri. Dalam opersi istisyhad, inti permasalahannya bukan terletak pada apakah operator terbunuh oleh senjatanya sendiri atau senjata orang lain, melainkan apa niat dan tujuan dari operasi tersebut. Jika sebuah operasi bom syahid bertujuan untuk merobekrobek moral tempur musuh dan pada saat yang sama mengantrol semangat jihad kaum Muslimin, maka operasi seperti itu sangat dianjurkan. Sebelum operasi istisybad--baik dengan atau tanpa bom--dilakukan, si operator harus menyadari atau memiliki asumsi kuat (dzan) bahwa ia bakal terbunuh. Untuk jihad bom syahid Bali mesti terjadi sebagaimana

28 Imam Samudra, Aku Melawan Teroris! (Solo: Jazera, 2004), h. 185. terjadinya istisyhad Kenya dan Tanzana, Adn (Yaman), WTC dan lain-lain. Latar belakang bom syahid Bali adalah sama dengan yang telah disebutkan di atas. Bahwa ini adalah perlawanan, bahwa ini adalah pembelaan, bahwa ini adalah jihad fi-sabilillah." ${ }^{29}$

Bagi pelaku teror, dalam situasi demikian hanya ada dua pilihan: mati syahid (mut syabidan) atau hidup mulia (isy kariman) menang menghancurkan Dajjal atau masuk surga. Musuh pelaku teror tidak terbatas orang (sistem) yang menolak kebenaran yang mereka yakini, tetapi juga pemeluk agama yang sama yang secara langsung (tidak) terlibat dalam kehidupan empirik dajjalis.

Memang tak banyak dipahami publik bahwa penganut teologi teroris, semua selain diri dan kelompoknya adalah sah, bahkan wajib dihancurkan. Apalagi terhadap orang yang selama ini menangkapi teman-temannya. Tidak peduli tempatnya di Mesjid (aksi bom bunuh diri di Mesjid Adz-Dzikro, Polresta Cirebon) yang bisa dituduh dibangun dengan uang kafir (dajjal) yang disebut Mesjid Dhiror sebagai bagian program deradikalisasi. Logika dan keyakinan pelaku teror sama sekali berbeda dengan logika publik. Bagi mereka, siapa saja yang tidak sepaham adalah musuh yang harus dihancurkan, apalagi yang jelas-jelas menentang keyakinan mereka.

Di sini teologi teror memberi tawaran dan jalan anak-anak muda yang selama ini memperoleh pendidikan agama berbasis logika hitam-putih, sehingga dengan mudah dijejali konsep syahid (mati surgawi) sebagai hero. Jika menang, maka sang hero dijanjikan kemuliaan hidup duniawi dan apabila mati, dijanjikan hidup abadi di surga beserta turunannya ditemani 40 bidadari. ${ }^{30}$

${ }^{29}$ Imam Samudra, Aku Melawan Teroris....., h. 182 dan 188.

${ }^{30}$ Bilveer Singh \& Abdul Munir Mulkhan, Jejaring Radikalisme Islam di Indonesia (Jogja: Bangkit Publisher, 2012), h. 59-67. 
Upaya penanggulangan terorisme menuntut sumbangan dari perspektif organisasional sebab terorisme merupakan aktivitas kelompok. Aksi bom bunuh diri memang sering dilakukan oleh individu, tetapi pasti didukung oleh jaringan aktor-aktor di belakang layar yang berperan mengatur perencanaan dan strategi. Untuk menghadapi hal demikian, intelijen dan aparat keamanan negara beetugas menguak jaringan tersebut dan membongkar modus operasinya.

Harus diingat, terorisme sering dimotivasi oleh faktor politik, sosial, ekonomi dan ideologi keagamaan. Pasalnya, terorisme sering dipicu oleh kepentingan untuk mempengaruhi kebijakan politik, bahkan untuk merebut kendali kekuasaan. Kelompok teroris yang kecewa atas kondisi negara termotivasi untuk mengubah kondisi politik melalui kekuasaan. Segala bentuk kekerasan menjadi pilihan jika kelompok teroris merasa berhadapan dengan sikap represif pemerintah, kurangnya kebebasan politik dan pendukungan asing.

Dalam bukunya, AWorld Without Islam, Fuller sebagaimana dikutip Irwan, berandaiandai seandainya tidak ada agama Islam di muka bumi pun terorisme akan tetap terjadi. Terorisme di Timur Tengah dan di belahan bumi lain tidak ada hubungannya dengan Islam. Fenomene terorisme adalah respons terhadap kondisi geopolitik dan berbagai isu sosial yang melibatkan komunitas muslim di dunia $^{31}$.

Fuller menyakini bahwa Islam tidak mengajarkan terorisme dan kekerasan yang dektruktif; yang terjadi adalah Islam yang mengajarkan jihad dengan makna yang cukup kompleks disalahgunakan untuk menjustifikasi kepentingan politik. Dengan pernyataan itu, Ia hendak mengatakan kebijakan luar negeri

${ }^{31}$ Irwan Masduqi, Berislam Secara Toleran : Teologi Kerukunan Beragama (Bandung: Mizan, 2011), h. 167-169.
Amerika dan sekutunya menjadi faktor yang memicu terorisme ${ }^{32}$.

Dengan memanfaatkan publikasi media massa, dunia cyber mereka sengaja menciptakan ketakutan-ketakutan dan keresahan yang mendalam di masyarakat. Warga dipancing agar marah terhadap pemerintah karena dinilai tidak mampu melindungi rakyatnya dan menuntut perubahan sistem pemerintah. Teroris yang anti demokrasi melakukan teror untuk membuktikan kegagalan demokrasi dan melaksanakan khalifah Islamiyah sebagai alternatif.

Terorisme di dunia Islam didorong oleh tujuan untuk menciptakan kehidupan Islami dengan menyerang isme-isme, insitusi-insitusi dan simbol-simbol yang tidak islami. Teror ini sangat dipicu oleh faktor determinan berupa doktrin kolot yang selama ini berkembang dalam tradisi pemikiran Islam sejak era kodifikasi.

Bagi Muhammad Shahrour budaya Islam telah dicemari oleh pemahamanpemahaman radikal bahwa "ayat-ayat pedang" telah menghapus ayat-ayat yang mengajarkan toleransi dan inklusivisme. Akibatnya, Islam yang awalnya mengajarkan kedamaian berubah menjadi ideologi kekerasan. Jihad yang mulamula hanya dilegalkan dalam rangka mempertahankan diri berubah menjadi perang ofensif demi tujuan ekspansi dan Islamisasi. Tanpa dihindari Islam pada dasarnya mengusung prinsif rahmat lil alamin (kasih sayang untuk semua) direduksi deremikian rupa oleh kelompok-kelompok konservatif, sehingga tampak seperti lanatan lil alamin (laknat untuk semua) yang menebarkan ancaman global.

Istilah seperti qital, qatl, ghazwu, syahadah dan syabid dikaitkan secara integral, sehingga menimbulkan kesan Islam meremehkan nilainilai kemanusiaan dan menisbahkan dosa kepada orang-orang melukai kehidupan dan

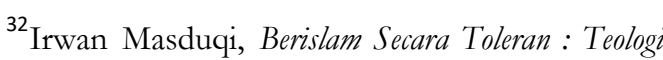
Kerukunan Beragama......, h. 165.
} 
membantu kematian. Tradisi fiqh Islam selalu memberi janji menggiurkan berupa imbalan surga yang dipenuhi bidadari bagi siapa pun yang gugur di medan perang. ${ }^{33}$

\section{Teologi Hakimiyah}

Istilah Hakimiyah baru dikenal di dunia Islam pada abad ke-14 Hijriah. Orang pertama yang melontarkannya adalah Abu al-A'la alMaududi, kemudian disusul oleh Sayyid Quthub. Sejak saat itu, istilah hakimiyah menyebar di kalangan jamaah-jamaah Islam. Adapun yang mereka maksud dengan istilah itu adalah menegaskan Allah dalam penerapan dan pembuatan hukum serta kekuasaan, semua legislasi dam pranata harus diambil dari-Nya. Jadi, menurut mereka, Hakimiyah hanya milik Allah, tidak ada seorang manusia pun yang boleh mengembannya.

Abu al-A'la al-Maududi mengatakan: "Kata ini, yakni Hakimiyah, disebutkan untuk menunjuk maksud kekuasaan tertinggi dan kekuasaan mutlak, sesuai dengan istilah yang berlaku dalam ilmu politik pada saat ini."

Juga mengatakan "Undang-undang ditetapkan berdasarkan kehendak pemegang hakimiyah, seperti orang wajib mematuhinya. Adapun pemegang Hakimiyah, maka tiadak ada lagi undang-undang yang mengaitkannya dan mengharuskannya untuk mematuhi seseorang. Dia adalah Maha Kuasa dengan kekuasaanya tak terbatas dalam zat-Nya. Tidak boleh ditanya, kenapa dia mengeluarkan undang-undang."

Selanjutnya, dia menegaskan: "Tidak ada seorang pun, selain Allah, yang ketetapan hukumnya boleh berlaku bagi hamba-hamba Allah. Kewenangan ini hanya milik Allah."

Sikap ini, kemudian diikuti oleh Sayyid Quthub yang mengatakan:

"Tidak seorang pun dari makhluk Allah yang berhak menetapkan hukum selain berdasarkan apa yang telah ditetapkan

${ }^{33}$ Irwan Masduqi, Berislam Secara Toleran : Teologi Kerukunan Beragama..., h. 97-99. oleh Allah dan diizinkan-Nya. Siapa pun dia. Hanya Allah-lah yang membuat dan menetapkan hukum bagi hamba-Nya, karena Dia-lah Pencipta alam semesta ini dan pengaturnya berdasarkan hukum-hukum umum dan besar yang dipilih-Nya. Sedangkan hidup manusia tidak lain kecuali gir kecil yang terdapat pada roda alam semesta yang sangat besar ini. Oleh kerena itu, harus diatur oleh hukum yang sejalan dengan hukum-hukum besar itu. Ini semua tidak mungkin terwujud, kecuali jika yang membuat hukum alah yang Maha Mengetahui seluk beluk hukum-hukum besar itu. Selanjutnya, tidak bisa disangka, bahwa siap pun selain Allah tidak akan mampu mengethaui seluk beluknya, sehingga tidak mungkin dipercaya untuk menetapkan hukum karen adanyanya ketidakmampuan itu."

Sayyid Quthub juga mengatakan:

"Sesungguhnya kewenangan menetapkan hukum hanya milik Allah. Kewenangan itu hanya terbatas bagiNya karena sifat uluhiyah-Nya. Hakimiyah adalah salah satu sifat khas uluhiyah-Nya. Barang siapa mengaku mempunyai hak itu, maka ia telah menyaingi Allah swt dalam sifat paling khusus dari ulubiyah-Nya. Siap pun yang mengaku itu, baik orang perorang, kelompok sosial tetetntu, partai, bdan, umat atau segenap umat manusia dalam bentuk organisasi internasional.

Sementara itu, barang siapa menyaingi dalam sifat khusus dari uluhiyah-Nya dan mengaku memilikinya, maka telah kafir dengan kekafiran yang nyata. Kekafirannya menjadi termasuk dalam kategori mengingkari unsur agama yang sudah pasti diketahui, sekalipun hanya berdasarkan dalil ini saja.

Pengakuan terhadap wewenang ini juga bukan satu-satunya faktor yang bisa mengeluarkan pengakuannya dari wilayah agama yang lurus dan menjadikannya telah menyaingi Allah dalam sifat paling khas dari ulubiyah-Nya. Dia tidak harus mengatakan; Aku tidak mengatahui ada Tuhan bagimu selain 
aku” (QS al-Qashash [28]:38); atau mengatakan: Aku Tuhanmu yang paling tinggi” (QS an-Naziat [79]:24); sebagaimana dikatakan oleh Firaun secara terang-terangan. Akan tetapi, dia sudah dianggap mengakui hak ini dan menyaingi Allah, dengan sekedar mengenyampingkan syariat Allah dari Hakimiyah dan mengambil undang-undang dari sumber lain. Juga dengan sekedar menyatakan bahwa pihak yang memiliki hak hakimiyah-- yakni yang menjadi sumber semua kedaulatan-adalah pihak lain selain Allah swt, meskipun pihak itu adalah keseluruhan bangsa atau keseluruhan umat manusia."

Dari penjelasan di atas, terlihat bahwa Hakimiyah, menurut mereka, termasuk salah satu dari pokok agama dan inti akidah, sehingga apabila tidak diterapkan atau ditolak, maka akan mengakibatkan kekafiran nyata. Hal ini mereka sarikan dari firman Allah swt:

"Barangsiapa tidak mennetapkan hukum dengan apa yang diturunkan Allah, amaka mereka itulah orang-orang kafir. (QS al-Maidah [5]:44)

Ketika menafsirkan ayat ini, Sayyid Quthub mengatakan:

"Dengan pertanyaan jelas dan tegas, serta keumuman yang terkandung dalam kata man (siapa) untuk menyatakan frasa syarat dan frasa jawab syarat (yang disyarati), sehingga terlepas dari ikatan waktu dan tempat dan menjadi ketentuan umum yang berlaku bagi setiap ornag yang tidak menetapkan hukum dengan apa yang telah diturunkan oleh Allah, dari generasi dan kelompok mana pun.

Adapun illat (latar belakang) hukumnya adalah sudah kami sebutkan, yakni bahwasanya orang yang tidak menetapkan hukum berdasarkan apa yang telah diturunkan oleh Allah, berarti telah menolak ulubiyah Allah. Salah satu sifat ulubiyah adalah penetapan hukum syariat. Dari sini, barangsiapa menetapkan hukum dengan selain yang diturunkan Allah, maka telah menolak uluhiyah Allah dan sifat-sifat khususNya dari satu sisi; dan di sisi lain, mengaku memiliki hak ulubiyah (wewenang ketuhanan) dan sifat-sifat khasnya. Lalu apa yang dimaksud dengan kekafiran jika bukan ini atau itu?

Apa nilai pengakuan iman dan Islam secara lisan, sedangkan perbuatansebagai ungkapan yang lebih kuat daripada perkataan-menyatakan kekafiran secara lebih fasih daripada lisan."

Dari sini, terlihat jelas bagi kita bahwa Hakimiyah, menurut mereka, menolak penetapan hukum yang dilakukan oleh manusia, bahkan menyerukan untuk memberontak kepadanya. Oleh karena itu, terbentuklah teori pemerintahan dalam Islam atas dasar pelucutan semua kekuasaan memerintah dan membuat hukum dari tangan manusia. Tidak ada seorang pun dari mereka yang diizinkah untuk mengeluarkan perintah kepada sesama mereka, lalu dipatuhi. ${ }^{34}$

Hakimiyah (kedaulatan Tuhan), dalam konsep ini dipahami bahwa dalam Islam pemerintahan adalah milik Tuhan sebagaimana makna Q.S. 5: 47. Anti-demokrasi, Thalib mengatakan, semua kekuasaan hanyak milik Allah dan hukum Allah harus menjadi landasan bagi semua pemerintahan Islam. Tuhanlah penguasa mutlak yang wajib dipatuhi semua makhluk. Thalib menyakinkan bahwa umat Islam dilarang mematuhi kehendak mayoritas rakyat karena sebagian besar dari mereka berada dalam kesesatan. Demokrasi bagi Jaeffar Umar Thalib adalah suatu cara pemerintahan yang prinsip-prinsipnya bertentangan dengan Islam. ${ }^{35}$

Bagi KH Hasyim Muzadi kemunculan paham radikalisme disebabkan: Pertama, faktor pengertian seseorang terhadap Islam dan

${ }^{34}$ Abdul Fattah Abdul Ghani al-'Awari, Konsep Hakimiyah, dalam buku Jihad Melawan Teror, Syekh Ahmad ath-Thayyib (Jakarta: Lentera Hati, Pusat Studi Al-Quran, 2016), h. 129-134.

${ }^{35}$ Moh. Sholehuddin, "Ideologi Religio-Politik Gerakan Salafi Laskar Jihad Indonesia", Jurnal Review Politik, Volume 03, No 1, Juni 2013, h. 55. 
penyalahgunaan Islam untuk kepentingan perorangan. Biasanya terlahir karena ekslusivisme Islam. Mereka hanya membenarkan kelompoknya sendiri, tidak bisa memegang teguh pendirian dan tidak dapat memahami kelompok lain dalam berIslam, sehingga ia merasa mewakili Islam dan Islam adalah dia. Kalau bukan karena dia tidak ada Islamnya. Dominasi ini melahirkan berbagai macam fanatisme, mulai dari yang lunak sampai paling berat.

Kedua, lakum dinukum walyadin yang diartikan sebagai pembenaran Islam saja tanpa pengakuan terhadap eksistensi agama yang lain. Padahal seharusnya kita tidak mengakui mereka, tetapi kita juga tidak ribut dengan mereka. Seterusnya mereka pun tidak boleh menganggu apa yang kita punya. Dalam perkembangannya waliyadin ini yang lebih mendominasi daripada lakum dinukum. ${ }^{36}$

Dalam pandangan Hasan Hanafi, sebagaimana dikutip Sholehuddin, lahirnya jemaah jihadi tak lepas dari teologi Hakimiyah dan jihad. Teologi Hakimiyah adalah keyakinan bahwa kedaulatan hanya di tangan Allah. Dengan demikian, hukum positif adalah sistem kafir. Oleh karena itu harus diganti dengan hukum Allah. Untuk kelompok pro kekerasan, teologi Hakimiyah tidak hanya melegitimasi pengkafiran terhadap sistem pemerintah demokrasi, tapi membenarkan tindakan-tindakan anarkis dalam rangka mengkudeta pemerintah dengan cara membunuh pemimpin dan menjarah uang negara ${ }^{37}$.

Sikap fundamentalisme radikal ini sungguh telah mencoreng citra Islam yang pada dasarnya adalah agama perdamaian. Ia menegaskan radikalisme dan terorisme atas nama Islam tidak dapat dibenarkan, sebab kata

${ }^{36}$ Hery Sucipto [ed], Islam Madzhab Tengah: Persembahan 70 Tabun Tarmizi Taher (Jakarta: Grafindo Khazanah Ilmu, 2007), h. 341-342.

${ }^{37}$ Moh. Sholehuddin, "Ideologi Religio-Politik Gerakan Salafi Laskar Jihad Indonesia......., h. 55.
"Islam" diambil dari akar kata yang sama dengan "salam" yang artinya damai. Islam dengan demikian adalah agama damai. ${ }^{38}$

Ahmad Syafii Maarif menegaskan dengan jelas, radikalisme agama dalam tingkat yang sangat akut dapat menyebabkan orang itu nekad melakukan bom bunuh diri dengan dalih jihad membela Islam dan umatnya. "Bagi saya bom bunuh diri sambil membunuh orang lain yang belum tentu bersalah adalah suatu kepiluan kemanusiaan yang sangat melukai nurani kita" ${ }^{39}$. Untuk kasus bom bunuh diri jelas berdasarkan konsep teologi yang sangat kacau, sebab tidak ada alasan rasional sama sekali dibelakangnya. Sesungguhnya peraktik serupa juga dilakukan oleh pemeluk Hindu di Indi yang secara radikal telah membunuh Indira Gandhi, di Srilanka oleh gerakan kemerdekaan Harimau Elam Yamil yang melawan kemerdekaannya.

Dari macam-macam sebab gerakan bunuh diri itu ada kerjasama penyebab utamanya; frutrasi, marah dan putus asa menghadapi realitas yang dinilai semakin kejam dan tak teratasi. Rupanya peribahasa "Daripada hidup becermin bangkal, lebih baik mati berkarang tanah" menjadi pegangan dalam bertindak. ${ }^{40}$

Hasil penelitian

Solahudin menunjukkan, gerakan Salafi memiliki konsep pemikiran tauhid sendiri. Begitu pula gerakan Salafi Jihadi dan DI. Eksponen DI menyusun konsep tauhid yang dikawinkan dengan pemikiran Abu A'la Al-Maududi dan Sayid Qutb. Dari situ lahir konsep Taubid Rububiyah, Taubid Mulkiyah, dan Taubid Ulubiyab (RMU). Eksponen Salafi menyusun konsep tauhid

38 Irwan Masduqi, Berislam Secara Toleran: Teologi Kerukunan Beragama....., h. 92-93.

${ }^{39}$ Ahmad Syafii Maarif, "Islam dan Bahaya Radikalisme Beragama," dalam kata pengantar buku Pray to Kill, M Haniff Hassan (Jakarta: Grafindo Khazanah Ilmu, 2006), h. XV-XXII.

${ }^{40}$ Ahmad Syafii Maarif, "Islam dan Bahaya Radikalisme Beragama......., h. XV-XXII. 
Ulubiyah, tauhid Rububiyah, dan tauhid Asma, sifat dan tauhid Hakimiyah.

Konsep tauhid dari tiga kelompok tersebut berbeda secara metodologis. Namun seiring dengan perjalanan sejarah, konsep tauhid versi DI yang pada akhirnya semakin mirip dengan doktrin tauhid Hakimiyah versi Salafi Jihadi.

Inti dari tauhid Hakimiyah adalah "pandangan bahwa kedaulatan politik sepenuhnya milik Allah". Konsep ini bertentangan dengan konsep kedaulatan menurut logika demokrasi. Sebagaimana diketahui bahwa demokrasi menempatkan kedaulatan rakyat sebagai kedaulatan politik tertinggi.

Tentunya, konsep tauhid Hakimiah memiliki dampak secara normatif dan empirik. Implikasi normatif muncul dalam bentuk pengkafiran atau pemurtadan terhadap orang yang tidak taat terhadap konsep tersebut. Penguasa yang menolah konsep tauhid Hakimiyah sama halnya dengan menolak syari'at Islam dan Hakimiyah. Bila mereka yang menolak tadi mengaku Muslim, berarti telah murtad. Memerangi penguasa murtad, menurut kelompok ini hukumnya fardlu 'ain. ${ }^{41}$

Dengan demikian, tindakan kekerasan yang bersumber dari teologi Hakimiyah bukan menjadi jalan terbaik dalam menyelesaikan segala persoalan. Oleh karena itu, umat Islam harus menyikapi persoalan radikalisme, terorisme ini dengan serius. Keterlibatan berbagai pihak dalam menangani masalah radikalisme dan terorisme sangat diharapkan. Tujuannya adalah untuk mempersempit ruang gerak radikalisme dan terorisme di Indonesia.

41 Muh Saerozi, "Jihadisme Salafi versus Pemikiran Mubaligh dan Guru Agama, Ijtihad: Jurnal Wacana Hukum Islam dan Kemanusiaan, Vol. 12, No. 1, Juni 2012:115-116. Baca juga Solahudin, NII sampai JI Salafy Jihadisme di Indonesia (Jakarta: Komunitas Bambu, 2011), h.28-29 \& 273

\section{Ijtihad Bersama}

Dalam perspektif al-Qur'an, Islam adalah sebuah agama yang mengharamkan setiap perbuatan yang merusak, membinasakan, melukai, dan membunuh tanpa alasan yang benar. Bahkan dalam peperangan sekalipun, prinsip-prinsip moral, akhlak, dan etika harus dijadikan pedoman dan acuan.

Cerita-cerita tentang kekejaman Fir'aun, kaum 'Ad, dan kaum Nuh yang durhaka adalah di antara gambaran klasik mengenai sikap dasar al-Qur'an yang menentang setiap bentuk perbuatan zalim, onar, dan melampaui batas. Fir'aun misalnya, dikatakan "sesungguhnya ia thaghâ" (perbuatan melampaui batas). Seperti kita ketahui, di antara kekejaman Fir'aun adalah memerintahkan aparatnya untuk membantai semua anak laki-laki karena khawatir akan mengganggu kekuasaannya, tetapi anak-anak perempuan dibiarkan hidup karena dinilai tidak berbahaya.

Dari ayat-ayat ini saja, dan masih banyak lain, kita dapat menyimpulkan bahwa Islam menyatakan perang terhadap segala bentuk kekerasan, kebiadaban, dan kezaliman, karena semuanya itu termasuk dalam karegori "perbuatan durhaka yang melampaui batas." Maka tidak disangsikan lagi bahwa terorisme adalah perbuatan biadab yang wajib dicegah dan dibasmi, siapa pun yang melakukan: perorangan, kelompok, ataupun negara.

Jangankan membunuh banyak orang melalui aksi teror, membunuh seorang anak manusia saja pun diharamkan, karena tindakan itu sama dengan membunuh seluruh umat manusia. Kita kutip terjemahan ayat berikut: “ ...Barangsiapa membunuh seseorang, bukan karena orang itu membunuh orang lain, atau bukan karena berbuat kerusakan di bumi, maka seakan-akan dia telah membunuh semua manusia. Barang siapa menjaga kehidupan seorang manusia, maka seakan-akan dia telah menjaga kehidupan seluruh manusia...." 
Terorisme hampir selalu berkaitan dengan persoalan politik dengan menggunakan kekerasan atau ancaman untuk mencapai tujuannya. Terorisme selalu menimbulkan ketakutan dan kengerian yang luar biasa dalam masyarakat. Terorisme tidak lain dari perbuatan pengecut yang teramat keji. Oleh sebab itu, Islam yang difahami secara benar, pasti menentangnya dari pangkal sampai ke ujung. ${ }^{42}$

Sejak awal, kaum Muslim dilarang membunuh orang yang tidak bertempur di medan perang, begitu pula anak-anak, wanita, biarawati dan rabi yang dijanjikan diberikan imunitas (jaminan, keselamatan) kecuali bila mereka ikut serta dalam peperangan itu.

Namun, bagaimana dengan adanya "ayat-ayat pedang", yang menyerukan untuk membunuh orang kafir, "Apabila sudah habis bulan-bulan Haram itu, maka bunuhlah orangorang musyrikin itu di mana saja kamu jumpai mereka, dan tangkaplah mereka. Kepunglah mereka dan intailah di tempat pengintaian." (Al-Taubah: 5).

Inilah salah satu ayat al-Quran yang dikutip para kritikus untuk menunjukkan bahwa kekerasan tidak dapat dipisahkan dari sifat dasar Islam dan kitabnya. Ayat yang sama juga dengan selektif digunakan (disalahgunakan) oleh ekstremis agama untuk mengembangkan "teologi kebencian" atau "teologi Hakimiyah" dan intoleransi demi menegaskan peperangan yang dilakukan tanpa alasan untuk menyerang orang kafir.

Memang kekerasan agama tumbuh secara eksponensial saat kaum Muslim dan non-muslim sama-sama menjadi korban terorisme global. Apalagi saat menghadapi aksi biadab di sebuah dunia yang tampaknya semakin berbahaya dan tak terkendali, kita dibanjiri oleh analisis dari para pakar teroris

${ }^{42}$ Ahmad Syafii Maarif, "Agama, Terorisme, dan Peran Negara," Maarif, Vol. 8, No. 1, Juli 2013, h. 246247 dan cendekiawan yang mempermasalahkan agama Islam atas terjadinya terorisme global.

Bersama dengan itu, kelompokkelompok teroris jaringan Al-Qaeda (ISIS) menyebarkan pesan ke seluruh dunia yang menyetankan Barat sebagai musuh Islam dan menuduhnya sebagai penyebab semua keperihan di dunia Muslim.

Di tengah retorika kebencian dan bertambahnya aksi dan paham kekerasan yang mengejawantahkan baik dalam bentuk antiAmerika di dunia Muslim maupun fobia-Islam di Barat, diskriminasi (kebencian) terhadap Islam (Muslim) semakin berkembang luas.

Berkenaan dengan ikhtiar melawan teroris, dalam Muktamar Internasional alAzhar untuk memerangi radikalisme dan terorisme pada bulan Desember 2014. Muktamar ini menghimpun tokoh-tokoh terkemuka dari Timur Arab, Islam serta dari dunia luas, baik dari kaum Muslim Sunni maupun Syiah, dari kaum Nasrani dengan berbagai sektenya.

Salah satu tujuannya untuk menjelaskan ciri-ciri hakiki ajaran Islam, mengungkap kesantunannya, kemudahan memahami ajarannya, penghormatannya kepada kemanusiaan manusia dan tujuan-tujuan luhur syaratnya yang harus diwujudkan dalam kehidupan manusia. ${ }^{43}$

Diadakannya Muktamar oleh Universitas al-Azhar bisa dilihat sebagai penanda bahwa radikalisme dan terorisme telah menjadi isu senteral dunia Islam, sehingga dituntut partisipasi dari semua pihak dalam penanggulangannya. Tentunya sesuai dengan kapasitas dan kemampuan masing-masing. ${ }^{44}$

${ }^{43}$ John L. Esposito \& Dalia Mogahed, Saatnya Muslim Bicara!: Opini Umat Muslim tentang Islam, Barat, Kekerasan, HAM dan Isu-isu Kontemporer Lainnya (Bandung: Mizan, 2008), h. 13-14 dan 41

${ }^{44}$ Syekh Ahmad ath-Thayyib et. al, Jihad Melawan Teror; Meluruskan Kesalabpahaman tentang Khilafah, Takfiri, Jihad, Hakimiyah, Jabiliyah dan Ekstremitas (Jakarta: Lentera Hati, Pusat Studi Al-Quran, 2016), h. vii 
Menurut Abdul Hayyi 'Izb Abdul 'Al, Rektor Universitas al-Azhar menjelaskan, terorisme tidak mempunyai agama. Bila orangorang itu memiliki metode aksi kekerasan dalam bentuk membunuh, menumpahkan darah, menghancurkan dan membuat kerusakan bagi orang Muslim dan nonMuslim. Dengan demikian mereka adalah musuh umat manusia. Terorisme, ekstremitas dan pengrusakan tidak punya agama dan tidak pula negara. Setiap orang yang menganut ideologi yang menebarkan teror kepada orangorang yang hidup aman, serta merusak tumbuhan dan hewan adalah teroris. ${ }^{45}$

Hal senada diungkapkan Zulfan Taufik bahwa tampilnya sisi gelap agama yang disambut berbagai kritik tajam tentunya tidak serta merta menghapus harapan besar terhadap kehadiran Islam dalam usaha menciptakan kehidupan yang lebih manusiawi. Islam justru berpotensi untuk menggarisbawahi tebal-tebal usaha tersebut. ${ }^{46}$

Islam tidak mengajarkan pemeluknya untuk merusak dan mengganggu keamanan hidup Muslim maupun non-Muslim. Islam hadir untuk memberikan kemudahan dan rasa aman. Itulah sebabnya syariat Islam dinamai alhanafiyah as-sambah karena mengandung unsur kemudahan dan pemudahan dalam segala perkara. Mudah, tengah-tengah dan moderat adalah sifat-sifat dan ciri terpenting dari ajaran Islam. $^{47}$

Memang sangat sulit untuk menyebut tindakan yang membolehkan membunuh, menumpahkan darah, menghancurkan dan

${ }^{45}$ Abdul Hayyi 'Izb Abdul 'Al, "Ekstremisme, Berlebih-lebihan, Jalan Tengah dan Moderasi serta Pengaruhnya terhadap Bangsa dan Negara",dalam buku Jihad Melawan Teror, Syekh Ahmad ath-Thayyib, Jakarta: Lentera Hati, Pusat Studi Al-Quran, 2016), h. 206-207.

46Zulfan Taufik, "Humanisme dan Ambivalensi Agama: Sinergi Pluralisme dan HAM dalam Menjaga Nilai Kemanusiaan", Titik Temu: Jurnal Dialog Peradaban, Vol. 7, No. 2, 2015.

${ }^{47}$ Abdul Hayyi 'Izb Abdul 'Al, "Ekstremisme, Berlebih-lebihan, Jalan Tengah dan Moderasi serta Pengaruhnya..........., h. 202. membuat kerusakan bagi kemanusiaan, sebagai tindakan yang berpijak pada ajaran Islam ini.

Kita tidak ingin konsep-konsep Islam yang dimaknai secara keliru dikonsumsi oleh umat Islam dalam skala luas. Jika tidak segera ditanggulangi tidak bisa dibayangkan seperti apa wajah generasi Islam di masa yang akan datang. Wajah Islam yang teduh dan penuh toleransi ini akan berubah menjadi sosok yang menakutkan. $^{48}$

\section{Kesimpulan}

Akar dan benih-benih paham keagamaan teologi Hakimiyah dengan pemahaman tafkirinya telah berkembang di Indonesia. Paham ini representasi dari berbagai aksi kekerasan atas nama agama, radikalisme, fanatisme, terorisme dan cara pandang menyelesaikan dengan cara-cara kekerasan dan berprasangka, berpikir negatif. Paham ini terdeteksi timbul bersamaan dengan tindak teorisme yang marak di Indonesia berdasarkan prinsip dan paham teologi yang mereka anut.

Berkembangnya paham teologi radikal ini bertolak belakang dengan upaya semua kalangan dalam penanggulangan radikalisme dan terorisme yang bukanlah persoalan sederhana, tetapi dibutuhkan usaha yang sistemik dan kerja sama banyak pihak. Di antara upaya yang harus segera dilakukan adalah menjelaskan ajaran Islam secara benar dan objektif pada satu pihak, dan meluruskan sejumlah kesalahpahaman dalam memaknai konsep-konsep Islam yang dijadikan pijakan oleh para pelaku terror ini.

Upaya semua pihak untuk memerangi terorisme ini perlu dukungan secara bersamasama. Seluruh dunia diharapkan untuk bersama-sama memboikot dan memerangi terorisme dan ekstremitas, dan tidak

${ }^{48}$ Syekh Ahmad ath-Thayyib et. al, Jihad Melawan Teror; Meluruskan Kesalabpahaman tentang Khilafah, Takfiri, Jihad, Hakimiyah, Jabiliyah dan Ekstremitas (Jakarta:Lentera Hati, Pusat Studi Al-Quran, 2016), h. vi. 
membiarkan hal itu dilakukan oleh negara tertentu, karena terorisme adalah musuh bersama bagi dunia. ${ }^{49}$

Dengan demikian, segala perilaku dan tindakan kekerasan atas nama agama yang mewujud dalam bentuk radikalisme, terorisme dan ajakan aksi bom bunuh diri yang bersumber dari teologi Hakimiyah itu bukan menjadi jalan terbaik dalam menyelesaikan segala persoalan yang dihadapi.

Upaya penyelesaian kasus kekerasan atas nama agama dapat dipelajari cara berIslam dari Kyai yang bersahaja dalam menjalankan hidup dengan berprasangka baik dan rendah hati. Ini yang dituliskan oleh Komaruddin Hidayat sebagai berikut:

"Suatu hari, saya datang pada seorang kiai untuk konsultasi agama. Saya bertanya, "Mengapa sesama Muslim, bahkan di antaranya adalah tokoh agama, suka mencemooh Muslim lain yang berbeda pendapat? Bahkan, adakalanya mengkafirkan serta menuduhnya sebagai ahli neraka. Kiai kampung tadi menjawab dengan datar. "Saya kurang tahu dalil apa yang dipakai. Kalau seseorang telah menyatakan dan menerima rukun iman dan rukun Islam, dia tidak berhak disebut kafir. Jadi, saya tidak bisa menjawab mengapa kita mesti mengkafirkan sesama Muslim serta sibuk mau mengukur kedalaman imannya. Saya sendiri tidak berani menjamin diri saya masuk surga, terlebih menuduh orang lain. Jadi maaf, coba saja tanyakan pada mereka yang suka mengukur-ukur ketakwaan orang"50.

Dari nasihat Kyai di atas, dapat diambil pelajaran hidup dengan bersangka baik dan rendah hati. Jangan merasa paling beriman dan bertakwa di hadapan orang lain. Saya teringat sebuah hadis, berbahagialah mereka yang

${ }^{49}$ Syekh Ahmad ath-Thayyib et. al, Jihad Melawan Teror; Meluruskan Kesalabpahaman tentang Khilafah, ........., h. 209.

50 Komaruddin Hidayat, Psikologi Beragama: Menjadikan Hidup Lebih Ramah dan Santun (Bandung: Hikmah [PT Mizan Publika],2010), h. 21-23 disibukkan dengan meneliti kesalahan dan kekurangan diri, lalu menutupinya dengan kebajikan daripada kerjanya sibuk melihat dan mengorek-ngorek kelemahan dan kesalahan orang lain. ${ }^{51}$

Tentunya, orang yang berpikir positif dan berprangsaka baik maka hidupnya akan lebih sehat dan damai. Sebaiknya, mereka yang selalu melihat dunia dari sisi negatif maka hidupnya akan sesak dan dunia tampak suram. ${ }^{52}$

\section{Daftar Pustaka}

\section{Buku Teks}

Abas, Nasir, Membongkar Jamaah Islamiyah: Pengakuan Mantan Anggota JI (Jakarta: Grafindo Khazanah Ilmu, 2009).

Abdul 'Al, Abdul Hayyi 'Izb, Ekstremisme, Berlebih-lebihan, Jalan Tengah dan Moderasi serta Pengarubnya terbadap Bangsa dan Negara, dalam buku Jihad Melawan Teror, Syekh Ahmad ath-Thayyib, (Jakarta: Lentera Hati, Pusat Studi AlQuran, 2016).

Al-'Awari, Abdul Fattah Abdul Ghani, Konsep Hakimiyah, dalam buku Jihad Melawan Teror, Syekh Ahmad ath-Thayyib (Jakarta: Lentera Hati, Pusat Studi AlQuran, 2016).

Andalas, Mutiara, Politik Para Teroris, (Yogyakarta: Kanisius, 2010).

Ath-Thayyib, Syekh Ahmad, et. al, Jihad Melawan Teror; Meluruskan Kesalahpahaman tentang Khilafah, Takfiri, Jihad, Hakimiyah, Jabiliyah dan Ekstremitas (Jakarta: Lentera Hati, Pusat Studi Al-Quran, 2016).

Hidayat, Komaruddin, Psikologi Beragama: Menjadikan Hidup Lebih Ramah dan Santun (Bandung: Hikmah [PT Mizan Publika], 2010).

51 Komaruddin Hidayat, Psikologi Beragama: Menjadikan Hidup Lebih Ramah dan Santun......., h. 2123.

${ }^{52}$ Ansyaad Mbai, Dinamika Baru Jejaring Teror di Indonesia (Jakarta: Squad Publishing, 2014), h. 35. 
Maarif, Ahmad Syafii, “Agama, Terorisme, dan Peran Negara," Maarif Vol. 8, No. 1, Juli 2013.

Maarif, Ahmad Syafii, "Islam dan Bahaya Radikalisme Beragama," dalam kata pengantar buku Pray to Kill, M Haniff Hassan, (Jakarta: Grafindo Khazanah Ilmu, 2006).

Maarif, Ahmad Syafii, Menerobos Kemelut: Refleksi Cendekiawan Muslim (Jakarta: Grafindo Khazanah Ilmu, 2005)

Masduqi, Irwan, Berislam Secara Toleran : Teologi Kerukunan Beragam (Bandung: Mizan, 2011).

Mbai, Ansyaad, Dinamika Baru Jejaring Teror di Indonesia (Jakarta: Squad Publishing, 2014).

Mogahed, John L. Esposito \& Dalia, Saatnya Muslim Bicara!: Opini Umat Muslim tentang Islam, Barat, Kekerasan, HAM dan Isu-isu Kontemporer Lainnya (Bandung: Mizan, 2008).

Muhammad, Afif, Agama dan Konflik Sosial: Studi Pengalaman Indonesia (Bandung: Marja, 2013).

Mulkhan, Bilveer Singh \& Abdul Munir, Jejaring Radikalisme Islam di Indonesia (Jogja: Bangkit Publisher, 2012).

Piliang, Yasraf Amir, Bayang-Bayang TubanAgama dan Imajinasi (Bandung: Mizan, 2011).

Qadar, Zuly, Gerakan Sosial Islam : Manifesto Gerakan Kaum Beriman, (Jogyakarta: Pustaka Pelajar, 2009).

Samudra, Imam, Aku Melawan Teroris (Solo: Jazera, 2004).

Shihab, Alwi, Islam Inklusif: Menuju Sikap Terbuka Dalam Beragama (Bandung: Mizan-AN Teve, 1997).

Solahudin, NII sampai JI Salafy Jihadisme di Indonesia (Jakarta: Komunitas Bambu, 2011)

Sucpto, Hery (editor), Islam Madz̧ab Tengah: Persembahan 70 Tahun Tarmizi Taher (Jakarta: Grafindo Khazanah Ilmu, 2007).
Syam, Nur, Tantangan Multikulturalisme Indonesia: Dari Radikalisme Menuju Kebangsaan Jogyakarta: KanisiusImpulse, 2009).

Wahyujatmiko, Nugroho (editor), Rentetan Peristiwa Bom di Indonesia (Jakarta: Yayasan Lazuardi Biru, 2012).

\section{Jurnal}

Azca, Muhammad Najib, "Yang Muda, Yang Radikal; Refleksi Sosiologis Terhadap Fenomena Radikalisme Kaum Muda Muslim di Indonesia Pasca Orde Baru", Maarif, Vol. 8, No. 1, Juli 2013.

Azra, Azyumardi, "Jihad dan Terorisme: Konsep dan Perkembangan Historis", Jurnal Islamika, Nomor 4, April-Juni, 1994

Bruinessen, Martin van, "Gerakan Sempalan di Kalangan Umat Islam Indonesia: Latar Belakang Sosio-Budaya," Ulumul Quran, Volume III No I, 1992.

Fanani, Ahmad Fuad, "Fenomena Radikalisme di Kalangan Kaum Muda", Maarif, Vol. 8, No. 1, Juli 2013.

Nurudin, "Basis Nilai-Nilai Perdamaian: Sebuah Antitesis Radikalisme Agama di Kalangan Mahasiswa", Jurnal Multikultural \& Multireligius, Vol. 12 No. 3, September-December 2013.

Saerozi, Muh, "Jihadisme Salafi versus Pemikiran Mubaligh dan Guru Agama", Ijtihad, Jurnal Wacana Hukum Islam dan Kemanusiaan, Vol. 12, No. 1, Juni 2012.

Sholehuddin, Moh., "Ideologi Religio-Politik Gerakan Salafi Laskar Jihad Indonesia", Jurnal Review Politik, Volume 03, No 1, Juni 2013.

Sugiyarto, Wakhid, "Jihad di Mata para Terpidana Terorisme di Indonesia", Harmoni, Volume VIII, Nomor 32, Oktober-Desember 2009.

Taufik, Zulfan, "Humanisme dan Ambivalensi Agama: Sinergi Pluralisme dan HAM dalam Menjaga Nilai Kemanusiaan", Titik Temu: Jurnal Dialog Peradaban, Vol. 7, No. 2, 2015. 